\title{
PENINGKATAN KEMAMPUAN BERPIKIR KRITIS SISWA MELALUI MODEL PROBLEM BASED LEARNING BERBANTUAN MEDIA KOTAK KEHIDUPAN PADA TEMA 6 CITA-CITAKU
}

\author{
Syarifa Rahma Amalia, Fina Fakhriyah, dan Sekar Dwi Ardianti
}

Universitas Muria Kudus

Email: syarifarahmaa@gmail.com; fina.fakhriyah@umk.ac.id; sekar.ardianti@umk.ac.id

\begin{tabular}{l}
\hline Info Artikel \\
\hline SejarahArtikel: \\
Diserahkan 2 Mei 2020 \\
Direvisi 11 Mei 2020 \\
Direvisi 16 Juni 2020 \\
Disetujui 16 Juni 2020 \\
\hline \\
Keywords: \\
problem based learning, \\
critical thinking ability, \\
life box
\end{tabular}

\begin{abstract}
This research described implementation of Problem Based Learning to improve teacher's teaching skill, the students' learning activities, and critical thinking ability of the students. This classroom action research was conducted for fourth graders of SD 1 Barongan Kudus. consisting of 41 students. It lasted in two cycles. The independent variables were Problem Based Learning model and life box. The dependent variables were critical thinking ability. Data collections in this research consist are test, observation, interview, and documentation. The data analysis were quantitative and qualitative.

The result showed improvement. Teacher's skill improved in cycle I, from 78.7 into 89.1 in cycle II. The students' learning activities improved from cycle I, 78.8 into cycle II, 88.6. Critical thinking ability of the students from cycle I, 73.2 improved into 86.8 in cycle II.It is concluded that critical thinking ability of the students could be improved through Problem based Learning model with life box media in SD 1 Barongan Kudus.
\end{abstract}

\begin{abstract}
Abstrak
Penelitian ini bertujuan untuk mendeskripsikan penerapan model Problem Based Learning terhadap peningkatan keterampilan guru dalam mengajar, aktivitas belajar siswa, dan kemampuan berpikir kritis siswa.

Penelitian tindakan kelas ini telah dilaksanakan di kelas IV SD 1 Barongan Kudus dengan subjek penelitian 41 siswa. Penelitian ini telah berlangsung dalam dua siklus.Variabel bebas dalam penelitian ini ialah model Problem Based Learning dan kotak kehidupan, sedangkan variabel terikatnya ialah kemampuan berpikir kritis. Teknik pengumpulan data dilakukan dengan teknik tes, observasi, wawancara, dan dokumentasi. Analisis data yang digunakan merupakan analisis data kualitatif dan analisis data kuantitatif.

Hasil penelitian menunjukkan adanya peningkatan. Keterampilan guru meningkat dari siklus I mendapatkan nilai 78,7 menjadi 89,1 pada siklus II, aktivitas belajar siswa meningkat dari siklus I mendapatkan nilai 78,8 menjadi 88,6 pada siklus II, dan kemampuan berpikir kritis siswa meningkat dari siklus I mendapat nilai rata-rata klasikal 73,2 menjadi 86,8 pada siklus II. Hal ini dapat disimpulkan bahwa kemampuan berpikir kritis siswa dapat meningkat melalui model pembelajaran Problem Based Learning berbantuan media kotak kehidupan di SD 1 Barongan Kudus.
\end{abstract}

(C) 2020 Universitas Muria Kudus 


\section{PENDAHULUAN}

Kurikulum di Indonesia telah berulang kali diperbaharui dan disempurnakan. Belen (dalam Ardianti et al, 2018) mencatat bahwa paling tidak telah terjadi perubahan kurikulum di Indonesia sebanyak sembilan kali, yaitu kurikulum tahun 1947, 1952, 1964, 1968, 1975, 1984, 1994, 2004, dan terakhir 2006. Penyempurnaan itu dilakukan berdasarkan perkembangan-perkembangan yang ada baik dari segi teknologi, perkembangan siswa, dan tuntutan standar yang ingin dicapai.

Perubahan-perubahan yang terjadi dalam kurikulum membawa kebaikan dalam setiap penyempurnaannya, hingga saat ini pada kurikulum 2013. Kurikulum 2013 menekankan pembelajaran tematik dan terpadu yang mengembangkan kemampuan berpikir kritis pada siswa. Fisher (2016) menyatakan berpikir kritis adalah pemikiran yang masuk akal dan reflektif yang berfokus untuk memutuskan apa yang mesti dipercaya atau dilakukan.

Kuswana (2013) menyebut bahwa seorang individu atau kelompok yang terlibat dalam berpikir kritis kuat dicirikan oleh adanya bukti melalui observasi atau penilaian berdasarkan kriteria dengan metode atau teknik dan pengambilan keputusan yang relevan dengan konteksnya. Adapun indikator berpikir kritis memuat lima aspek yaitu, memberikan penjelasan sederhana, membangun keterampilan dasar, menyimpulkan, memberikan penjelasan lanjut, mengatur strategi dan taktik (Susanto, 2016)

Salah satu kemampuan berpikir kritis yang harus dikuasai siswa terdapat pada mata pelajaran Bahasa Indonesia pada materi puisi dan Ilmu Pengetahuan Alam (IPA) pada materi lingkungan sekitar. Dalam materi mengenai puisi tentang alam maka sejalanlah muatan Bahasa Indonesia dan IPA.

Berdasarkan uji pra siklus mengenai kemampunan berpikir kritis siswa kelas IV SD 1 Barongan Kudus pada 7 November 2018, diketahui bahwa dari 41 siswa, 32 siswa dalam kriteria pelu bimbingan, satu siswa dalam kriteria baik, tujuh siswa dalam kriteria cukup, dan hanya satu siswa dalam kriteria sangat baik. Secara klasikal kemampuan berpikir kritis siswa prasiklus mendapatkan nilai rata-rata klasikal sebesar 60.

Dalam pelaksanaan pembelajaran ditemukan siswa kurang menguasai kompetensi dasar pengetahuan muatan pembelajaran Bahasa Indonesia dan IPA terutama pada materi sumber daya alam. Siswa hanya membayangkan dan tidak melihat secara langsung sehingga pembelajaran kurang bermakna. Belum tersedianya media yang mendukung menyebabkan guru kurang optimal dalam pelaksanaan pembelajaran. Aktivitas belajar siswa juga rendah sehingga kemampuan berpikir kritis siswa rendah, kurang optimal, dalam menanggapi permasalahan dan memecahkan suatu masalah seperti soal yang diberikan guru.

Berdasarkan kondisi tersebut, diperlukan alternatif tindakan untuk meningkatkan kemampuan berpikir kritis siswa melalui pembelajaran yang menarik. Dalam hal ini dirancang pembelajaran yang siswa terlihat aktif dalam berdiskusi, menganalisis dan mengemukakan gagasannya. Pembelajaran ini juga didukung dengan penggunaan media pembelajaran yang inovatif dan menarik perhatian siswa, sehingga siswa lebih semangat dalam pembelajaan. Maka dari itu diterapkan model pembelajaran Problem Based Learning berbantuan media kotak kehidupan.

Murtono (2017) menyatakan bahwa model pembelajaran Problem Based Learning ini merupakan model yang efektif untuk pengajaran proses berpikir tingkat tinggi. Pembelajaran berbasis masalah menekankan masalah kehidupannya yang beramakna bagi siswa dan peran guru dalam menyajikan masalah, mengajukan pertanyaan, dan memfasilitasi penyelidikan dan dialog sehingga dengan penerapan model ini, membantu siswa untuk memahami pembelajaran tema cita-citaku materi daur hidup, sumber daya alam dan puisi dikarenakan model ini menekankan pemecahan masalah dan mendukung dalam meningkatkan kemampuan berpikir kritis siswa.

Secara umum ada lima tahap kegiatan pembelajaran yang berorientasi pada model Problem Based Learning. Trianto (Murtono, 2017) menyebutkannya yaitu (1) Orientasi siswa kepada masalah. (2) Organisasikan siswa untuk belajar. (3) Membimbing penyelididkan individual maupun kelompok. (4) Mengembangkan dan menyajikan hasil karya. (5) Menganalisis dan mengevaluasi.

Pembelajaran dengan Problem Based Learning memberikan pengalaman belajar yang bermakna bagi siswa yang difokuskan untuk menjembatani siswa agar memperoleh pengalaman belajar dalam mengorganisasikan, meneliti, dan memecahkan masalah-masalah kehidupan yang kompleks sehingga lebih memahami materi dan sesuai dengan tujuan 
dari kurikulum 2013. Sudah banyak riset yang dilakukan dengan menggunakan model Problem Based Learning antara lain penelitian Zuliana (2014), riset Santoso dan Oktavianti (2015), serta Susanto, Masturi, dan Ismaya (2018) namun riset yang dilakukan berbeda dengan penelitian tersebut diatas.

\section{METODE PENELITIAN}

Jenis penelitian yang digunakan yaitu penelitian tindakan kelas (PTK). Desain penelitian ini yaitu model Kemmis dan Mc Taggart, meliputi empat tahapan diantaranya perencanaan, pelaksanaan tindakan, observasi dan refleksi.

Subjek penelitian ini yaitu siswa kelas IV SD 1 Barongan Kecamatan Kota Kabupaen Kudus dengan jumlah 41 siswa, jumlah siswa perempuan 23 dan laki-laki 18 siswa. Penelitian dilaksanakan dalam 2 siklus dan masing-masing siklus terdiri dari 2 pertemuan. Siklus I dilaksanakan pada tanggal 21 Januari22 Januari 2019 dan siklus II pada tanggal 30 Januari-31 Januari 2019. Penelitian dilakukan pada tema 6 Cita-Citaku, subtema 2 Hebatnya Cita-Citaku serta subtema 3 Giat Berusaha Meraih Cita-Cita, masing-masing pada pembelajaran 1 dan 2 .
Teknik pengumpulan data yang digunakan dalam penelitian ini yaitu tes dan non tes. Tes dalam penelitian ini yaitu tes pra siklus dan tes evaluasi akhir tiap siklus. Non tes digunakan untuk mengumpulkan data berupa aspek sikap dan aspek keterampilan. Tes pra siklus dilaksanakan pada tanggal 7 November 2018. Tes yang dilaksanakan pada setiap akhir siklus baik siklus I maupun siklus II dengan model Problem Based Learning berbantuan media kotak kehidupan. Tes evaluasi untuk mengukur kemampuan berpikir kritis aspek pengetahuan siswa terdiri dari 8 soal uraian, yang disusun dengan mengacu pada indikator berpikir kritis. Non tes untuk mengukur kemampuan berpikir kritis aspek sikap dan aspek keterampilan.

Penelitian ini menggunakan analisis data kuantitatif dan kualitatif. Data kuantitaif berupa tingkat pemahaman yang mengukur tingkat pemahaman siswa. Data kuantitatif berupa tingkat pemahaman kognitif dan berbentuk bilangan. Hasil tes dan nontes siswa dianalisis dengan mengacu tabel kriteria menurut Panduan Penilaian SD Kurikulum 2013 yang dapat dilihat pada Tabel 1.

Tabel 1. Kriteria Kemampuan Berpikir Kritis Siswa

\begin{tabular}{cccc}
\hline No. & Nilai & Kriteria & Predikat \\
\hline 1. & $92<\mathrm{x} \leq 100$ & Sangat Baik & $\mathrm{A}$ \\
2. & $83<\mathrm{x} \leq 92$ & Baik & $\mathrm{B}$ \\
3. & $75 \leq \mathrm{x} \leq 83$ & Cukup & $\mathrm{C}$ \\
4. & $\mathrm{x}<75$ & Perlu Bimbingan & $\mathrm{D}$ \\
\hline
\end{tabular}

Cara menghitung nilai rata-rata klasikal menggunakan rumus:

Nilai $=\frac{\text { jumlah siswa yong whtos }}{\text { jumah selwhh siswa }} x 100$

\section{HASIL DAN PEMBAHASAN}

Hasil penelitian pra siklus yang telah dilakukan pada siswa kelas IV SD 1 Barongan, diperoleh nilai rata-rata klasikal dengan nilai 60 dengan kriteria perlu bimbingan. Kemampuan berpikir kritis siswa aspek pengetahuan diperoleh nilai rata-rata klasikal 60 dengan kriteria perlu bimbingan, aspek sikap diperoleh nilai rata-rata klasikal senilai 63 dengan kriteria perlu bimbingan, aspek keterampilan diperoleh nilai rata-rata klasikal senilai 61,3 dengan kriteria perlu bimbingan.

Pada siklus I kemampuan berpikir kritis siswa aspek pengetahuan diperoleh nilai rata-rata klasikal 74,2 dengan kriteria perlu bimbingan, aspek sikap diperoleh nilai ratarata klasikal senilai 73,4 dengan kriteria perlu bimbingan, aspek keterampilan diperoleh nilai rata-rata klasikal senilai 74,5 dengan kriteria perlu bimbingan. Pada siklus I siswa sudah berani bertanya kepada guru akan tetapi masih banyak yang malu-malu dalam memberikan penjelasan sederhana sehingga terbata-bata, siswa masih kesulitan dalam membuat keputusan dengan cepat saat diskusi kelompok atau tanya jawab, dan siswa tidak mempertimbangkan hasil diskusi kelompoknya dengan mengkroscek kembali, terbukti dengan jawaban siswa dalam evaluasi yang kurang maksimal. Rekapitulasi hasil kemempuan berpikir kritis aspek pengetahuan, aspek sikap, dan aspek keterampilan siklus I dapat dilihat pada Tabel 2. 
Syarifa Rahma Amalia, Fina Fakhriyah, dan Sekar Dwi Ardianti

PENINGKATAN KEMAMPUAN BERPIKIR KRITIS SISWA MELALUI MODEL ...

WASIS: Jurnal Ilmiah Pendidikan. Volume 1, Nomor 1, Mei 2020, hlm. 7-13

Tabel 2. Rekapitulasi Hasil Kemampuan Berpikir Kritis Siklus I

\begin{tabular}{|c|c|c|c|c|}
\hline \multirow{2}{*}{ Indikator } & \multirow{2}{*}{ Aspek yang diamati } & \multicolumn{3}{|c|}{ Rata-Rata Nilai Kemampuan Berpikir Kritis } \\
\hline & & Pengetahuan & Sikap & Keterampilan \\
\hline \multirow{3}{*}{1.} & Memfokuskan & 71 & - & - \\
\hline & Menganalisis & 68 & - & - \\
\hline & Bertanya & - & - & 81 \\
\hline \multirow{2}{*}{2.} & Mempertimbangkan & 71 & - & - \\
\hline & Menyelesaikan & 75 & - & - \\
\hline \multirow{3}{*}{3.} & Menyusun & 72 & - & - \\
\hline & Keputusan & - & 71 & - \\
\hline & Hasil & - & - & 68 \\
\hline \multirow{3}{*}{4.} & Mengaitkan & 82 & - & - \\
\hline & Menanggapi & 76 & - & - \\
\hline & Alasan & 75 & - & - \\
\hline \multirow{2}{*}{5.} & Tindakan & - & 78 & - \\
\hline & Berinteraksi & - & 71 & - \\
\hline \multicolumn{2}{|c|}{ Nilai Rata-rata } & 74,2 & 73,4 & 74,5 \\
\hline \multicolumn{2}{|c|}{ Nilai Rata-rata Klasikal } & \multirow{2}{*}{\multicolumn{3}{|c|}{$\begin{array}{c}73,2 \\
\text { Perlu Bimbingan }\end{array}$}} \\
\hline \multicolumn{2}{|c|}{ Kriteria } & & & \\
\hline
\end{tabular}

Tabel 2 menunjukkan bahwa kemampuan berpikir kritis siswa pada siklus I dalam kriteria perlu bimbingan. Pada siklus I kemampuan siswa terkait memberikan penjelasan sederhana pada aspek pengamatan menganalisis argumen masih kurang. Soal Problem Based Learning mengarahkan siswa untuk membedakan antara informasi yang baik dan buruk, serta dapat mengambil keputusan yang tepat dalam menganalisis argumen (Fakhriyah et al, 2016).

Hasil kemampuan berpikir kritis siswa meningkat pada siklus II, dengan diperoleh nilai rata-rata klasikal senilai 86,8 dengan kriteria baik, kemampuan berpikir kritis siswa aspek pengetahuan diperoleh nilai rata-rata klasikal 85,3 dengan kriteria baik aspek sikap diperoleh nilai rata-rata klasikal senilai 88,6 dengan kriteria baik, aspek keterampilan diperoleh nilai rata-rata klasikal senilai 88,5 dengan kriteria baik. Pada siklus II siswa telah mengalami peningkatan dalam memberikan penjelasan sederhana. Rekapitulasi hasil kemampuan berpikir kritis aspek pengetahuan, aspek sikap, dan aspek keterampilan siklus II dapat dilihat di Tabel 3.

Tabel 3. Rekapitulasi Hasil Kemampuan Berpikir Kritis Siswa Siklus II

\begin{tabular}{|c|c|c|c|c|}
\hline \multirow{2}{*}{ Indikator } & \multirow{2}{*}{ Aspek yang diamati } & \multicolumn{3}{|c|}{ Rata-Rata Nilai Kemampuan Berpikir Kritis } \\
\hline & & Pengetahuan & Sikap & Keterampilan \\
\hline \multirow{3}{*}{1.} & Memfokuskan & 83 & - & - \\
\hline & Menganalisis & 79 & - & - \\
\hline & Bertanya & - & - & 92 \\
\hline \multirow{2}{*}{2.} & Mempertimbangkan & 89 & - & - \\
\hline & Menyelesaikan & 86 & - & - \\
\hline \multirow{3}{*}{3.} & Menyusun & 89 & - & - \\
\hline & Keputusan & - & 87 & - \\
\hline & Hasil & - & - & 86 \\
\hline \multirow{3}{*}{4.} & Mengaitkan & 90 & - & - \\
\hline & Menanggapi & 84 & - & - \\
\hline & Alasan & 84 & - & - \\
\hline \multirow{2}{*}{5.} & Tindakan & - & 91 & - \\
\hline & Berinteraksi & - & 90 & - \\
\hline \multicolumn{2}{|c|}{ Nilai Rata-rata } & 85,3 & 88,6 & $\mathbf{8 8 , 5}$ \\
\hline \multicolumn{2}{|c|}{ Nilai Rata-rata Klasikal } & & 86,8 & \\
\hline \multicolumn{2}{|l|}{ Kriteria } & & Baik & \\
\hline
\end{tabular}


Pada Tabel 3 dapat diketahui, kemampuan berpikir kritis siswa siklus II pada kriteria baik. Hasil ini meningkat senilai 13,6 dari siklus I. Peningkatan kemampuan berpikir kritis siswa dapat dilihat pada Grafik 1.

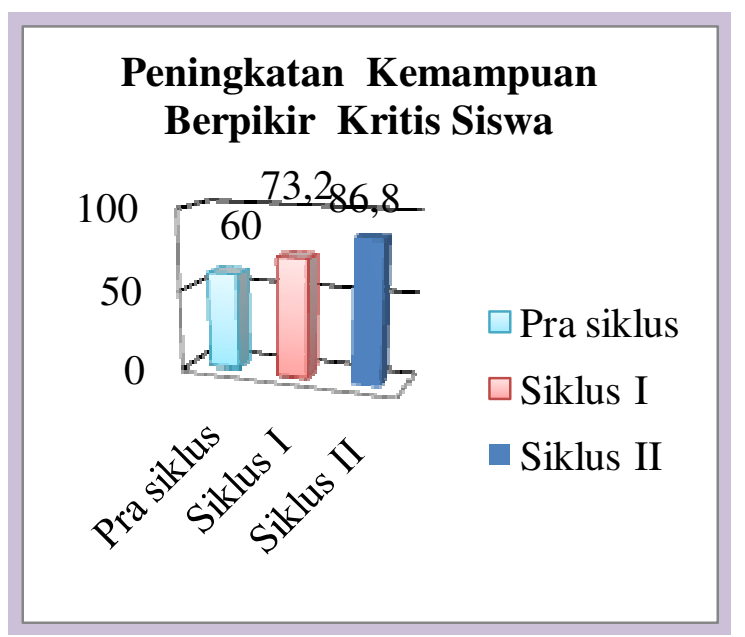

Grafik 1. Diagram Peningkatan Kemampuan Berpikir Kritis Siswa

Berdasarkan hasil penelitian, dapat dikatakan bahwa penerapan model Problem Based Learning (PBL) berbantuan media kotak kehidupan dapat meningkatkan kemampuan berpikir kritis siswa kelas IV SD 1 Barongan Kudus. Hasil penelitian juga sejalan dengan penelitian yang dilakukan oleh Nafiah (2014) dimana penerapan model PBL dalam pembelajaran materi perbaikan dan setting ulang PC dapat meningkatkan keterampilan berpikir kritis siswa sebesar $24,2 \%$. Hal ini dipahami bahwa dengan strategi pembelajaran problem based learning anak mampu mengembangkan berpikir kritisnya. Lebih lanjut Kiptiyah, Ismaya, dan Ahsin (2019) menemukan bahwa penerapan model Open Ended berbantuan media peta dapat meningkatkan kemampuan berpikir kritis pada tema 5 ekosistem siswa kelas V SDN Tluwuk.

Peningkatan kemampuan berpikir kritis siswa juga dikarenakan penggunaan media pembelajaran. Joekendi (2017) menyatakan bahwa penggunaan media tiga dimensi dapat meningkatkan keaktifan siswa dalam pembelajaran IPA materi gunung api. Peningkatan didasarkan pada hasil pratindakan hanya $45 \%$ dari keseluruhan siswa yang aktif. Pada siklus 1 menjadi $60 \%$ pada pertemuan pertama $70 \%$ pertemuan kedua dan siklus 2 meningkat lagi menjadi
80\%. Arsyad (Herawati, 2016) mengatakan bahwa media pembelajaran dapat memperjelas penyajian pesan dan informasi sehingga dapat memperlancar dan meningkatkan proses dan hasil belajar. Media pembelajaran juga dapat meningkatkan dan mengarahkan perhatian anak sehingga dapat menimbulkan motivasi belajar, interaksi yang lebih langsung antara siswa dan lingkungannya, dan kemungkinan siswa untuk belajar sendiri-sendiri sesuai dengan kemampuan dan minatnya. Dikuatkan oleh Falahudin (2014) istilah media berasal dari bahasa Latin yang merupakan bentuk jamak dari "medium" yang secara harafiah berarti perantara atau pengantar. Makna umumnya adalah segala sesuatu yang dapat menyalurkan informasi dari sumber informasi kepada penerima informasi. Istilah media ini sangat populer dalam bidang komunikasi. Proses belajar mengajar pada dasamya juga merupakan proses komunikasi, sehingga media yang digunakan dalam pembelajaran disebut media pembelajaran.

Arsyad (Herawati ,2016) menguraikan bahwa memilih media harus memperhatikan beberapa kriteria dalam memilih media, yaitu: (1) sesuai dengan tujuan yang ingin dicapai, (2) tepat untuk mendukung isi pelajaran yang sifatnya fakta, konsep, prinsip, atau generalisasi, (3) praktis, luwes, dan bertahan, (4) guru terampil menggunakannya, (5) pengelompokan sasaran, dan (6) mutu teknis. Menurut Daryanto (Supriadi, et al, 2017), media tiga dimensi adalah sekelompok media tanpa proyeksi yang penyajiannya secara tiga dimensional. Kelompok media ini dapat berwujud sebagai benda asli baik hidup maupun mati, dan dapat pula berwujud sebagai tiruan yang mewakili aslinya. Dikuatkan oleh Jonkenedy (2017) bahwa media tiga dimensi sangat cocok untuk meningkatkan keaktifan siswa karena penyajiannya kongkrit dan menghindari verbalisme, sehingga siswa akan aktif dalam proses pembelajaran. Mengacu pada media tiga dimensi, pada kotak kehidupan merupakan media tanpa proyeksi yang penyajiannya secara tiga dimensional berwujud sebagai benda tiruan yang mewakili aslinya. Pada penelitian ini, kotak kehidupan merupakan media yang penyajiannya secara tiga dimensional berwujud benda tiruan yang mewakili aslinya yang terbuat dari plastisin dan gabus yang ditempel dengan gambar hewan serta kotak yang didalamnya menyajikan gambaran kehidupan nyata tentang bentang alam. 
Hasil penelitian yang dilakukan memiliki persamaan dan perbedaan dengan penelitian Khamdun (2014), riset Khakim, Utaminingsih, dan Fakhriyah (2015), penelitian Wati, Utaminingsih, dan Fakhriyah (2015), dan riset Malik (2019). Adapun persamaannya pada pemilihan mata pelajaran IPA. Sementara itu perbedaannya pada subyek, fokus dan rumusan penelitian.

Penelitian Khamdun menyimpulkan bahwa metode inkuiri terbimbing dalam pembelajaran IPA dapat meningkatkan hasil belajar siswa. Selanjutnya riset Khakim, Utaminingsih, dan Fakhriyah (2015) menyimpulkan bahwa penerapan model CTL dapat meningkatkan hasil belajar IPA siswa materi sifat-sifat cahaya di kelas V SD 1 Peganjaran.

Penelitian Wati, Utaminingsih, dan Fakhriyah (2015) penerapan model Pembelajaran Berbasis Masalah (PBM) dapat meningkatkan hasil belajar IPA siswa materi daur air di kelas V SD Negeri Pasuruhan Pati. Selanjutnya Riset Augraheni (2018) menemukan bahwa Hasil validasi ahli dan praktisi menunjukkan bahwa Rencana Pelaksanaan Pembelajaran yaitu 87,62 berada pada kategori baik dan Lembar Kerja Siswa (LKS) yaitu 81,90 berada pada kategori baik. Oleh karena itu perangkat pembelajaran matematika berbasis pendidikan karakter kreatif layak digunakan di kelas IV Sekolah Dasar.

Riset Malik (2019) menunjukan bahwa hasil belajar IPA tentang menggolongkan hewan berdasarkan jenis makanannya dengan menggunakan metode diskusi kelompok pada siswa kelas IV SD 1 Sidorekso dapat meningkat. Dari kondisi awal rata-rata nilai tes formatif 61,48 dengan persentase tuntas $29,63 \%$ dan persentase tifak tuntas $70,37 \%$. Hasil siklus I meningkat rata-rata 68,15 dengan persentase tuntas $66,67 \%$ dan persentase tidak tuntas $33,33 \%$. Hasil siklus II rata-rata naik menjadi 73,70 dengan persentase tuntas $96,30 \%$ dan persentase tidak tuntas $3,70 \%$.

\section{SIMPULAN}

Berdasarkan penelitian tindakan kelas yang Berdasarkan analisis dan pembahasan, dapat disimpulkan bahwa dengan penerapan model Problem Based Learning berbantuan media kotak kehidupan dapat meningkatkan kemampuan berpikir kritis siswa kelas IV SD 1 Barongan Kudus. Penerapan model Problem Based Learning akan memberikan pembelajaran yang bermakna dengan penggunaan media kotak kehidupan sehingga dapat mengembangkan cara berpikir dan kreativitas dalam memecahkan suatu permasalahan dengan cara meningkatkan konsentrasi siswa. Untuk memaksimalkan pembelajaran, sebaiknya guru mempersiapkan terlebih dahulu pertanyaan yang akan digunakan baik dari segi bahasa maupun konten kalimat yang disesuaikan dengan tingkat pemahaman siswa uang akan memancing siswa untuk berpikir dan siswa sebaiknya memaksimalkan media kotak kehidupan untuk memperoleh informasi lebih detail mengenai materi yang akan dipelajari.

\section{DAFTAR PUSTAKA}

Ardianti, Sekar Dwi., Ulya, Himmatul., dan Ismaya, Erik Aditia. 2018. PAKEM DALAM KURIKULUM 2013 : Teori dan Praktek. Kudus: Badan Penerbit Universitas Muria Kudus.

Fakhriyah, Fina., Sumaji., dan Roysa, Mila. 2016. Pengaruh Model Problem Based Instruction dalam Mengembangkan Kemampuan Berpikir Kritis Siswa Sekolah Dasar. Jurnal Konseling GUSJIGANG. 2 (1): 781-790.

Falahudin, Iwan. 2014.Pemanfaatan Media dalam Pembelajaran. Jurnal Lingkar Widyaiswara, 1 (4): 104-117.

Fisher, Alec. 2016. Berpikir Kritis. Jakarta:Penerbit Erlangga.

Herawati, Sufi. 2016. Pemanfaatan Media Pembelajaran Gambar Berseri Untuk Meningkatkan Kemampuan Menulis Karangan Sederhana Pada Siswa Kelas III. Widyagogik, 3 (3): 35-44.

Jonkenedi. 2017. Penggunaan Media Tiga Dimensi untuk Meningkatkan Keaktifan Siswa dalam Pembelajaran IPA. Jurnal Pendidikan Guru Sekolah Dasar, 6 (6), 590-598.

Khakim., Utaminingsih, Sri., dan Fakhriyah, Fina. 2015. Penerapan Model Contextual Teaching and Learning Melalui Pemanfaatan Lingkungan Sekitar Untuk Meningkatkan Hasil Belajar IPA Kelas V SD 1 Peganjaran Kudus. Refleksi Edukatika : Jurnal Ilmiah Kependidikan, 5 (1). 


\section{Syarifa Rahma Amalia, Fina Fakhriyah, dan Sekar Dwi Ardianti \\ PENINGKATAN KEMAMPUAN BERPIKIR KRITIS SISWA MELALUI MODEL ... \\ WASIS: Jurnal Ilmiah Pendidikan. Volume 1, Nomor 1, Mei 2020, hlm. 7-13}

Khamdun. 2014. Peningkatkan Hasil Belajar IPA Melalui Inkuiri Terbimbing Pada Siswa SDN I Ngembalrejo Bae Kudus. Refleksi Edukatika : Jurnal Ilmiah Kependidikan, 4 (2): 1-9.

Kiptiyah, W., Ismaya, Erik Aditia., dan Ahsin, Muhammad Noor. 2019. Peningkatan Kemampuan Berpikir Kritis Melalui Model Open Ended Berbantuan Media Peta Tema 5 Ekosistem Pada Siswa Kelas V SDN Tluwuk. Skripsi. Kudus: Universitas Muria Kudus.

Kuswana, Wowo Sunaryo. 2013. Taksonomi Berpiikir. Bandung: PT Remaja Rosdakarya.

Malik, Jamaludin. 2019. Penerapan Metode Diskusi Kelompok Untuk Meningkatkan Hasil Belajar IPA Dan Aktivitas Siswa Kelas IV SD I Sidorekso Pada Materi Menggolongkan Hewan Berdasarkan Jenis Makanannya. Refleksi Edukatika : Jurnal Ilmiah Kependidikan, 9 (2): 128-133.

Murtono. 2017. Merencanakan dan Mengelola Model-Model Pembelajaran Inovatif. Kudus:Wade Group.

Nada, Izzatun., Utaminungsih, Sri., dan Ardianti, Sekar Dwi. (2018). Penerapan Model Open Ended Problems Berbantuan CD Pembelajaran untuk Meningkatkan Kemampuan Berpikir Kreatif Siswa Kelas IV SD 1 Golantepus. JPSD, 4 (2): 216-227.

Nafiah, Yunin Nurin. 2014. Penerapan Model Problem-Based Learning untuk Meningkatkan Keterampilan Berpikir Kritis dan Hasil Belajar Siswa. Jurnal Pendidikan Vokasi, 4 (1): 125-143.

Nofiadi, Selamet., Listyorini, Tri., Susanto, Arief. 2017. Animasi Metamorphosis Kupu-kupu. Jurnal SIMETRIS, 8 (1): 299-308.
Oktavianti, Ika dan Santoso, S. 2015. Peningkatan Hasil Belajar PKn Siswa Kelas VI SD 3 Jekulo Kudus Melalui Model Problem Based Learning. Refleksi Edukatika : Jurnal Ilmiah Kependidikan, 5 (1).

Sadiman., Asyad, Azhar., danMahanani, Chytra. 2014. Media Pendidikan Pengertian, Pengembangan, dan Pemanfaatannya. Jakarta: PT Raja Grafindo Persada.

Sani, Ridwan Abdullah. 2014. Pembelajaran Saintifik untuk Implementasi Kurikulum 2013. Jakarta: Bumi Aksara.

Sugiyono. 2016. Metode Penelitian Pendidikan. Bandung: Alfabeta.

Supriadi, Bambang., Maghfiroh, Ayu Fajarotul., dan Lesmono, Albertus Djoko. 2017. Pengaruh Model Problem-Based Learning (PBL) disertai Media Tiga Dimensi Terhadap Kemampuan Berpikir Kreatif Siswa dan Hasil Belajar Siswa dalam Pembelajaran Fisika Di SMA Negeri 4 Jember. Jurnal Pembelajaran Fisika, 6 (1): 33-39.

Susanto, Ahmad. 2016. Teori Belajar dan Pembelajaran. Jakarta: Prenamedia Group.

Susanto, Dwi., Masturi., dan Ismaya, Erik Aditia. 2018. Penerapan Model Problem Based Learning Berbantu Media Puzzle Untuk Meningkatkan Hasil Belajar Pada Pembelajaran Ips Di Kelas V SDN Sumbersari 01. Skripsi. Kudus: Universitas Muria Kudus.

Wati, Nanik Istika., Utaminingsih, Sri., dan Fakhriyah, Fina. 2015. Penerapan Model Pembelajaran Berbasis Masalah (PBM) Untuk Meningkatkan Hasil Belajar IPA Siswa di Kelas V SD Negeri Pasuruhan Pati. Jurnal Ilmiah Kependidikan, 5 (1): 1-7.

Zuliana, Eka. 2015. Pengaruh Model Problem Based Learning Berbantuan Kartu Masalah Terhadap Kemampuan Pemecahan Masalah Matematika Siswa Sekolah Dasar. Refleksi Edukatika : Jurnal Ilmiah Kependidikan, 5 (1). 